\title{
ANTACID ANTICHOLINERGIC REGIMENS IN PATIENTS UNDERGOING ELECTIVE CAESAREAN SECTION
}

\author{
Dayid M. Dewan, A. Scott Wheeler, Francis M. James III, \\ Herbert M. Floyd and Leonard Rhyne
}

\begin{abstract}
The $\mathrm{pH}$ and volume of gastric contents were examined in 60 patients undergoing elective Caesarean Section under thiopentone, nitrous oxide-oxygen, succinylcholine anaesthesia. All patients received Gelusil ${ }^{\mathbb{6}} 30 \mathrm{ml}$ per os preoperatively, while 20 were given atropine $7 \mu \mathrm{g} \cdot \mathrm{kg}^{-1}$ and another 20 glycopyrrolate $4 \mu \mathrm{g} \cdot \mathrm{kg}^{-1}$ intramuscularly along with Gelusi ${ }^{\text {. }}$. Following tracheal intubation, gastric fluid was sampled through an orally placed 18 French Salem Sump tube.

After Gelusil ${ }^{\$}$ alone, the mean gastric fluid pH was $4.54 \pm 2.45$ (SD) while it was significantly higher following the combined use of antacid and atropine $(6.78 \pm 1.20)$ or antacid and glycopyrrolate $(6.42 \pm 1.72),(P<0.01)$. Differences in gastric fluid volume between the groups were insignificant.

All three regimens produced a gastric $\mathrm{pH}$ greater than 2.5 when given less than 75 minutes before sampling. When the premedication to sampling interval exceeded 75 minutes the addition of atropine or glycopyrrolate decreased the incidence of gastric $\mathrm{pH}$ less than 2.5 from 47 per cent in patients given Gelusil ${ }^{\text {B }}$ alone to 6 per cent and 14 per cent, respectively. In comparison to Gelusil ${ }^{\oplus}$ alone, this difference was significant with atropine $(P<0.05)$ but not with glycopyrrolate. Atropine and glycopyrolate respectively produced 6 per cent and 7 per cent incidences of $\mathrm{pH}$ lower than 2.5 combined with gastric volume greater than $25 \mathrm{ml}$, which were significantly lower than was observed with Gelusil ${ }^{\circ}$ alone (P $<0.05$ ).

This study demonstrates that the addition of atropine or glycopyrrolate to Gelusil ${ }^{\circledast}$ premedication provides additional protection against the consequences of aspiration, especially when the premedication to anaesthetic induction period is prolonged.
\end{abstract}

Key Words: Premedication, antacid, atropine, glycopyrrolate; Caesarean SECTION, acid aspiration.

ASPIRATION of gastric contents remains a leading cause of maternal mortality. Recent maternal mortality statistics from Great Britain showed the risk of death from anaesthesia among parturients to be between $1 / 6000$ and $1 / 7500$ operations. ' This death rate included 36 deaths associated with general anaesthesia of which 16 or 44 per cent involved aspiration of gastric contents. Since between 90 per cent and 100 per cent of these anaesthetic deaths had a preventable fac-

David M. Dewan, M.D., Assistant Professor; A Scott wheeler, M.D., Associate Professor; Francis M. James III, M.D., Professor; Herbert M. Floyd, M.D., Assistant Professor; Department of Anaesthesia. Leonard Rhyne, Ph.D., Professor, Department of Family Practice and Community Medicine; Bowman Gray School of Medicine of Wake Forest University, Winston-Salem, North Carolina 27103 U.S.A.

Presented in part at the Annual Meeting, American Society of Anesthesiologists, October 15, 1980.

Requests for reprints to Dr. Dewan. tor, clearly there remains much room for improvement in the area of aspiration. ${ }^{1}$

Laboratory work indicates that the $\mathrm{pH}$ and volume of the aspirate are critical factors in determining the degree of pulmonary injury produced by aspiration. ${ }^{2,3}$ Gastric contents exceeding a volume of $0.4 \mathrm{ml} / \mathrm{kg}$ with a $\mathrm{pH}$ below 2.5 are more likely to cause sequelae if aspirated. Therefore, either increasing gastric $\mathrm{pH}$ or decreasing gastric volume improve the prognosis when aspiration occurs. Antacid therapy effectively increases gastric $\mathrm{pH}$ but does not always produce a $\mathrm{pH}$ above $2.5 .^{4}$ The anticholinergic agent glycopyrrolate both raises $\mathrm{pH}$ and decreases gastric volume, but also does not always raise the $\mathrm{pH}$ above $2.5 .^{5} \mathrm{We}$ therefore examined the efficacy of combining glycopyrrolate with an antacid to determine whether this combination presents advantages over the use of either the antacid alone or over the more com- 
TABLE I

age, Weight, and Premedication to Sampling Interval in Patients given Gelusil ${ }^{\$}$, Gelusil PLUS ATROPINE, AND GELUSIL PLUS GlyCOPYRROLATE. ( $n=20$ per group.)

\begin{tabular}{lccc}
\hline \hline & Gelusil & Gelusil + Atropine & Gelusil + Glycopyrrolate \\
\hline Age (yrs) & $24.7 \pm 5.1$ & $25.5 \pm 5.7$ & $27.6 \pm 5.4$ \\
Weight (kg) & $75.8+13.9$ & $75.9 \pm 11.6$ & $75.9 \pm 16.1$ \\
Sampling Interval (min) & $85 \pm 17$ & $84 \pm 16$ & $85 \pm 18$ \\
\hline
\end{tabular}

Mean \pm Standard Deviation

monly used anticholinergic, atropine, together with the antacid.

\section{Methods}

Sixty healthy term parturients scheduled for elective Caesarean Section under general anesthesia were included in the study after they had given informed consent. The Human Research Practices Committee approved the protocol. Twenty patients were assigned to each of three premedication regimens: one group received Gelusil ${ }^{\oplus}, * 30 \mathrm{ml}$ by mouth; another group Gelusil $30 \mathrm{ml}$ by mouth and atropine $7 \mu \mathrm{g} \cdot \mathrm{kg}^{-1}$ intramuscularly; and the third group Gelusil $30 \mathrm{ml}$ by mouth and glycopyrrolate, $4 \mu \mathrm{g} \cdot \mathrm{kg}^{-1}$ intramuscularly. All premedications were given as close to 60 minutes preoperatively as possible.

Anaesthesia was induced with intravenous thiopentone $3 \mathrm{mg} \cdot \mathrm{kg}^{-1}$ and the trachea was intubated after an intravenous bolus of succinylcholine $1.2 \mathrm{mg} \cdot \mathrm{kg}^{-1}$. Nitrous oxide-oxygen (2:1) was then administered while muscle relaxation was maintained with an intravenous infusion of succinylcholine 0.1 per cent. Immediately after delivery of the baby a \# 18 Salem Sump tube was passed orally and the gastric content was aspirated as completely as possible with a $50 \mathrm{ml}$ syringe. Patient groups were compared for age, weight, interval from premedication to gastric sampling time, gastric volume and $\mathrm{pH} \dagger$ using analysis of variance and the Dunkins new multiple range test. The Fischer exact test was employed to determine the significance of the varying incidences. Significance was assumed when $\mathrm{P}<0.05$.

\section{RESULTS}

The groups were similar regarding age,

*Gelusil ${ }^{\mathbb{B}}$ - Wamer/Chilcott - each $5 \mathrm{ml}$ contains $200 \mathrm{mg}$ aluminum hydroxide, $200 \mathrm{mg}$ magnesium hydroxide, $25 \mathrm{mg}$ simethicone.

$\lceil$ Fischer Acumet pH Meter, Model 1212. weight, and interval between premedication and sampling (Table I).

Gastric volume did not differ among the groups. Mean $\mathrm{pH}$ was lower with Gelusil ${ }^{\circledast 2}$ alone in contrast to when Gelusil was given with an anticholinergic drug $(P<0.01)$. Atropine and glycopyrrolate in combination with Gelusil produced similar elevations of $\mathrm{pH}$.

Despite the mean $\mathrm{pH}$ in all three groups being well above 2.5 , thirty-five per cent of patients who had received only Gelusil had a gastric $\mathrm{pH}$ less than 2.5. By comparison, the addition of atropine or glycopyrrolate decreased the incidence of pH less than 2.5 to 5 per cent and 10 per cent respectively (Table II). This difference was statistically significant for both atropine and glycopyrrolate.

The three drug regimens were effective for all patients in maintaining $\mathrm{pH}$ above 2.5 when the interval between premedication and sampling was less than 75 minutes. When the interval exceeded 75 minutes, 47 per cent of patients who had been given Gelusil had a pH less than 2.5, while the incidence when atropine and glycopyrrolate were used was six per cent and 14 per cent respectively (Table III). In comparison to the Gelusil group, the incidence of gastric $\mathrm{pH}$ less than 2.5 was significantly lower in the atropine $(P<0.05)$ but not in the glycopyrrolate group, even though the effects of atropine and glycopyrrolate were similar.

All but one of the patients with a pH less than 2.5 had a gastric volume exceeding $25 \mathrm{ml}$, which increases the danger of aspiration. The $40 \mathrm{per}$ cent incidence of $\mathrm{pH}$ less than 2.5 combined with a volume exceeding $25 \mathrm{ml}$ seen with Gelusil alone was significantly higher in comparison to the six per cent and seven per cent incidences seen with atropine or glycopyrrolate (Table III).

\section{DISCUSSION}

Indications for general anaesthesia in obstetrics persist. Aspiration of gastric contents may 
TABLE II

Mean Gastric Volume and pH ( \pm S.D.) and InCIDEnCE (PER CEnt) OF Gastric pH Less than 2.5 in Patients given Gelusil 30 ML by Mouth, Gelusil 30 ML By Mouth Plus Atropine $7 \mu \mathrm{g} \cdot \mathrm{kg}^{-1}$ Intramuscularly, OR GelusiL $30 \mathrm{ML}$ By MOUTH PLUS GLYCOPYRROLATE $4 \mu \mathrm{g} \cdot \mathrm{kg}^{-1}$ INTRAMUSCULARLY. ( $\mathrm{n}=20$ per group)

\begin{tabular}{lccc}
\hline \hline & Gelusil & Gelusil+Atropine & Gelusil+Glycopyrrolate \\
\hline Volume (m) & $37 \pm 22$ & $31 \pm 18$ & $26 \pm 14$ \\
$\mathrm{pH}$ & $4.54 \pm 2.46 \dagger$ & $6.78 \pm 1.20$ & $6.42 \pm 1.72$ \\
$\mathrm{pH}<2.5^{*}$ & $35 \%(7 / 20) \ddagger$ & $5 \%(1 / 20)$ & $10 \%(2 / 22)$ \\
\hline
\end{tabular}

*Per cent of patients with gastric $\mathrm{pH}<2.5$ with (n) representing number of effected patients per group.

$\dagger \mathrm{p}<0.01, \mathrm{pH}$ in Gelusil subjects versus $\mathrm{pH}$ in both Gelusil + anticholinergic groups.

$\ddagger \mathrm{p}<0.05$, incidence of $\mathrm{pH}<$ in Gelusil ${ }^{\$}$ group versus incidence in Gelusil ${ }^{\circledR}+$ atropine and Gelusil ${ }^{\text {क }}+$ glycopyrrolate groups.

TABLE III

INCIDENCE (PER CENT) OF GASTRIC PH LESS THAN 2.5 AND GASTRIC PH LESS THAN 2.5

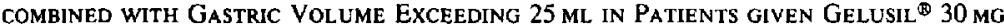
by Mouth, Gelusil ${ }^{\$}$ Plus atropine $7 \mu \mathrm{g} \cdot \mathrm{kg}^{-1}$, OR Gelusil Plos Glycopyrrolate $4 \mu \mathrm{g} \cdot \mathrm{kg}^{-1}$ When Premedication to Sampling InTERVAl Exceeds 75 Minutes*

\begin{tabular}{lccc}
\hline \hline & $\begin{array}{c}\text { Gelusil } \\
(\mathrm{n}=15)\end{array}$ & $\begin{array}{c}\text { Gelusil+Atropine } \\
(\mathrm{n}=16)\end{array}$ & $\begin{array}{c}\text { Gelusil+Glycopyrrolate } \\
(\mathrm{n}=14)\end{array}$ \\
\hline $\mathrm{pH}<2.5$ & $47 \%(7 / 15) \dagger$ & $6 \%(1 / 16)$ & $14 \%(2 / 14)$ \\
$\mathrm{pH}<2.5$ and \\
$\mathrm{Vol}>25 \mathrm{ml}$ & $40 \%(6 / 15) \ddagger$ & $6 \%(1 / 16)$ & $7 \%(1 / 14)$ \\
\hline
\end{tabular}

*Incidence is reported as percent of patients with (n) representing number of effected patients per group.

tp $<0.05$, incidence of gastric $\mathrm{pH}$ less than 2.5 with Gelusil alone vs incidence with Gelusil plus atropine.

$\ddagger \mathrm{p}<0.05$, incidence of gastric $\mathrm{pH}$ less than 2.5 and volume exceeding $25 \mathrm{ml}$ with Gelusil alone vs incidence with Gelusil and atropine and Gelusil with glycopyrrolate.

occur despite all precautions aimed at prevention, including rapid induction of anaesthesia and tracheal intubation accompanied by cricoid pressure. Prophylactic oral antacids have not elminated the problem. They do not guarantee a $\mathrm{pH}$ above 2.5. Furthermore, aspiration of particulate antacids has produced pulmonary injury in dogs. ${ }^{6}$ Significant pulmonary problems can also follow the aspiration of gastric contents with a pH of 3.5. ${ }^{7}$ Salem's findings that glycopyrolate $\left(7.5-10 \mu \mathrm{g} \cdot \mathrm{kg}^{-1}\right.$ increased $\mathrm{pH}$ and decreased gastric volume in children would make its use in obstetrics attractive. ${ }^{5}$ However Baraka, ${ }^{8}$ using $0.4 \mathrm{mg}$ of glycopyrrolate, irrespective of patient weight, failed to observe changes of gastric volume in the parturient, and Stoelting ${ }^{9}$ found volume and $\mathrm{pH}$ unchanged when using a standard $0.2 \mathrm{mg}$ dose in non-pregnant adults. Our anticholinergic doses fall between those of Salem and Stoelting and this may explain why there were no statistically significant changes in gastric volume in our study. Increased doses of glycopyrrolate might have produced significant changes in volume. Furthermore, employing a more accurate method to measure gastric volume such as a dye dilution technique might also have altered our results. Our volumes are, if anything, falsely low.

The changes in gastric $\mathrm{pH}$, as opposed to the changes in volume, were significant. The addition of glycopyrrolate to Gelusil ${ }^{\star 2}$ increased mean $\mathrm{pH}$ and decreased the incidence of a low $\mathrm{pH}$, in contrast to Gelusil alone; but atropine, in the dose used, was equally effective (Tables II, III).

Gelusil alone proved more reliable than had been anticipated. With shorter premedication to sampling times of less than 75 minutes it was 100 per cent effective. Beyond 75 minutes it was much less reliable (Tables II, III). Roberts observed the same 100 per cent effectiveness before 75 minutes when using a combination of 
magnesium and aluminum hydroxide. ${ }^{3}$ The addition of atropine and glycopymolate appeared to extend the time of effectiveness of Gelusil. This continued elevation of $\mathrm{pH}$ in the face of probable diminishing antacid effect, coincides with the time of maximal effect of glycopyrrolate seen by Baraka. ${ }^{8}$ The continued coverage seen also with atropine may reflect the larger dose used in this study as compared with Stoelting who found no effect with atropine alone. ${ }^{9}$ This longer duration of coverage provides protection during emergence when the patient's airway may once more be unprotected. Since premedication to induction and especially induction to emergence times may be prolonged, the use of anticholinergic appears warranted to provide this longer period of protection.

Glycopyrrolate and atropine do have the disadvantage of decreasing lower oesophageal sphincter tone ${ }^{10}$ and so increasing the chances of regurgitation; but properly applied cricoid pressure can overcome this problem.

In summary, the addition of either glycopyrrolate or atropine to a Gelusil ${ }^{10}$ premedication in the parturient undergoing elective Caesarean Section reduces the number of patients with gastric $\mathrm{pH}$ less than 2.5 , so decreasing the likelihood of aspiration pneumonitis when premedication has been given more than 75 minutes before operation.

\section{REFERENCES}

1. Morr, D. Maternal mortality and anaesthesia. Br. J. Anaesth. 52: 1 (1980).

2. Teabeaut, J.R. III. Aspiration of gastric contents, an experimental study. Am. J. Pathol. 28: 51 (1952).

3. Roberts, R.B. \& ShIRLEy, M.A. Reducing the risk of acid aspiration during cesarean section. Anesth. Analg. 53: 859 (1974).

4. TAYLOR, G. \& Pryse-Davies, J. The prophylactic use of antacids in the prevention of the acid pulmonary aspiration syndrome (Mendelson's syndrome). Lancet 2: 288 (1966).

5. Salem, M.R., Wong, A.Y., MaNi, M., et al. Premedicant drugs and gastric juice $\mathrm{pH}$ and volume in pediatric patients. Anesthesiology 44: 216 (1976).

6. Gibes, C.P., Schwartz, D.J. \& WynNe, J.W.: Antacid pulmonary aspiration in the dog. Anesthesiology 51: 380 (1979).

7. TAYLOR, G. Acid pulmonary aspiration syndrome after antacids. Br. J. Anaesth. 47:615 (1975).

8. Baraka, A., SaAb, M., Salem, M., et al. Control of gastric acidity by glycopyrrolate premedication in the parturient. Anesth. Analg, 56: 642 (1977).

9. StOel tiNG, R. Responses to atropine, glycopyrrolate, and riopan of gastric $\mathrm{pH}$ and volume in adult patients. Anesthesiology 48: 367 (1978).

10. Brock-UTNE, J.G., Robin, J., Wilman, S., $e t$ al. The effects of glycopyrrolate (Robinul) on the lower oesophageal sphincter. Can. Anaesth. Soc. J. 25: 144 (1978).

\section{RÉSUMÉ}

Le $\mathrm{pH}$ et le volume du contenu gastrique ont été mesurés sur 60 femmes anesthésiées au thiopental, protoxyde-oxygène et succinylcholine lors de césariennes en chirurgie réglée. Elles avaient toutes reçues Gelusil ${ }^{\boxplus 3} 30 \mathrm{ml}$ per os à la période préopératoire, médication à laquelle furent ajoutés atropine $7 \mu \mathrm{g} \cdot \mathrm{kg}^{-1}$ dans 20 cas et glycopyrrolate $4 \mu \mathrm{g} \cdot \mathrm{kg}^{-1}$ dans 20 autres cas. Après l'intubation endotrachéale, le liquide gastrique fut aspiré à l'aide d'une sonde Salem Fr 18.

Après Gelusil ${ }^{\circledR}$ seul, le pH moyen du liquide gastrique a été mesuré à $4.54 \pm 2.45$ (ET) alors qu'il fut plus élevé de façon significative à la suite de l'association antiacide-atropine $(6.78 \pm 1.2)$ ou antiacide-glycopyrrolate $(6.42 \pm 1.72),(\mathrm{P}<0.01)$. La différence de volume entre les groupes n'a pas été significative.

Les trois prémédications ont produit un $\mathrm{pH}$ gastrique de plus de 2.5 lorsqu'administrées à moins de 75 minutes avant l'échantillonnage. Lorsque l'intervalle entr la prémédication et l'échantillonnage a dépassé 75 minutes l'addition d'atropine ou de glycopyrrolate a diminué l'incidence d'acidité à $\mathrm{pH}$ de moins de 2.5 de 40 per cent pour les patientes au Gelusil ${ }^{\$}$ seul à 6 pour cent et 14 pour cent respectivement pour les autres prémédications. En comparaison avec le Gelusil seul, cette différence a été significative pour l'atropine ( $\mathrm{P}<$ $0.05)$ mais non pour le glycopyrrolate. L'atropine et le glycopyrrolate ont permis de réduire a 6 et 7 pour cent respectivement l'incidence d'acidité plus basse que 2.5 s'associant à un volume gastrique plus grand que $25 \mathrm{ml}$, ce qui était significativement plus bas qu'avec le Gelusil seul $(P<0.05)$.

Cette étude tend à démontrer que l'addition d'atropine ou de glycopyrrolate au Gelusil ${ }^{\oplus}$ en prémédication permet une protection additionnelle contre les effets nocifs de l'aspiration lorsque la période qui sépare la prémédication de l'induction se prolonge. 